\title{
Factors affecting nest site selection of Milvus migrans govinda (Pariah kite), in and around AMU campus, Aligarh
}

\begin{abstract}
Pariah Kite Milvus migrans govinda is a widely distributed resident kite of the Indian subcontinent with reasonably good population and presently serving as one of the major facultative scavengers in most of the urban centers, holding importance as after the Indian sub-continent has almost lost its primary natural scavenger, White-rumped vulture (Gyps bengalensis), since the 1990's from most of its range. A better management can help maintain its good population and one such crucial component, understanding its nesting site selection within the urban area, was the focus of our study. We investigated the various parameters such as substrate type, substrate height, nest height, GBH, canopy cover above the nest, green cover and distance from foraging sites of all the active nest $(n=70)$ found. The Pearson product-moment correlation coefficient was found highly positively significant with tree height, GBH and foraging site distance favoring the nesting site selection. Highly negative significant correlation with canopy cover and the green cover was found indicating its selectiveness towards more urban areas food is available. Also less canopy cover on the nest tree signifies for easy entry-exit to the nest as it has large wingspan and also for better vigilance. Also, the circular plots were plotted around the nest sites and random sites to compare the parameters between the utilized and available sites. The mean differences in the parameters came out to be significantly different, suggesting that the pariah kites are selective in nature for nest site selection.
\end{abstract}

Keywords: pariah kite, nest site, gbh, green cover, urbanization
Volume 3 Issue 4 - 2018

Amee Mehta, Orus llyas

Department of Wildlife Sciences, Aligarh Muslim University, India

Correspondence: Orus llyas, Department of Wildlife Sciences, Aligarh Muslim University, Aligarh-202002, India, Email orus16@gmail.com

Received: June 13, 2018| Published: July II, 2018

\section{Introduction}

Nests of birds have been compared to the mammalian uterus which provides warmth and protection to the developing embryo. An individual's fecundity and survival are likely to depend upon the choice of nest site which may, in turn, determine the structure and growth rate of population, and also the evolution of species. ${ }^{1-3}$

Natural selection favors individuals that choose resources that enhance breeding success, which maintains the population but limited availability of such resources can limit the number of individuals that breed. In a given species, nest site quality varies in space and time at different scales due to different environmental factors affecting reproductive success. ${ }^{4}$ Other environmental factors, besides nest site characteristics, which can have a strong influence on reproductive success is food availability.

Being free from persecution and with the adequate food supply, the urban landscapes often serve as ideal and safe habitats for raptors. ${ }^{5}$ Urban landscape produces a great diversity of habitats ranging from near natural to completely artificial. These habitats are characterized by small patch size of vegetation, intensive human management, an abrupt change in structure and high anthropogenic interference. ${ }^{6}$

Milvus migrans govinda is a widely distributed resident kite of the Indian subcontinent with reasonably good populations. it presently serves as one of the major facultative scavengers in most of the urban areas. $^{7}$ This particular habit has helped evolve and adapt this species successfully in the urban areas. It holds even more importance after Indian sub-continent has almost lost its primary scavenger, Whiterumped vulture (Gyps bengalensis), since the 1990s from most of its distribution range. ${ }^{8}$ The existence of PARIAH Kite, the govinda subspecies, as the secondary scavenger proves vital. ${ }^{9}$
Therefore, it is important to maintain its good population it is important to understand the behavioral characteristics especially the nest selection that allow kites to adapt to a highly urban landscape, nest amidst human habitation and forage on dump refuse. ${ }^{9}$

Hence, Study on nest site section by Pariah kite (Milvus migrans govinda) in the urban landscape of Aligarh was carried out to know the factors affecting the selection of nesting habitat, nest substrate characteristics and its implications for management of the species for conservation purpose.

\section{Study area}

The study was conducted in the campus of Aligarh Muslim University (AMU), Aligarh $\left(27.9135^{\circ} \mathrm{N}, 78.0782^{\circ} \mathrm{E}\right)$; covering an area of about $4.21 \mathrm{~km}^{2}$. It was divided into ten study sites by stratified stratified manner on the basis amount of green cover and degree of urbanization differentiated by the help of Google earth Program; Stratifying the sites from most green covered to most urbanize. The climate is semi-arid, with $727 \mathrm{~mm}$ of annual precipitation which is mainly concentrated in July and August. Temperature ranges from a mean maximum of $40.1^{\circ} \mathrm{C}$ to a minimum of less than $7.1^{\circ} \mathrm{C}$ in winters (India Meteorological Department 2018). The vegetation of the region falls within the 'northern tropical thorn forest' category (Champion \& Seth 1968) (Figure 1).

Study sites included Jamalpur, being the market area with butcher shops which was most urbanized whereas Qila and Naqvi Park were semi-forested, with plantation and less human inhabitation. Other sites were urban colonies, hospital area, university area with huge buildings and roads. All areas had a minimum of $30 \%$ of green cover including Naqvi Park and Qila having the most up to $90 \%$. 


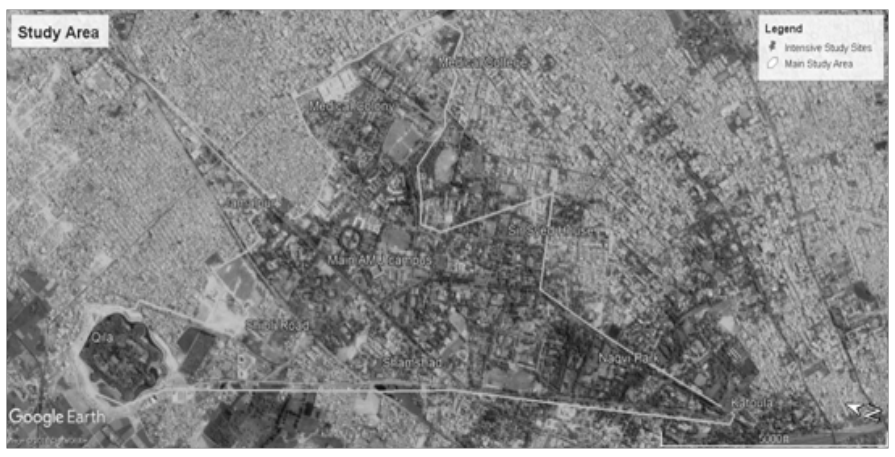

Figure I Study area with 10 study sites.

\section{Methodology}

The fieldwork spanned from January 2018 to May 2018 encompassing one breeding period of the Pariah kite in North-central region in India. ${ }^{7,10}$ All study sites were intensively searched for 'active nest' i.e. when an individual or pair was repeatedly observed to perch on the nest or its immediate surroundings. ${ }^{6}$ As the sites were located, type of substratum for nesting and its GPS location was taken and monitored every week. An alphanumeric code was allotted to each site comprising of abbreviations-type of site: $\mathrm{N}=$ nest; the number of the site and intensive study area in which it is located: JM=Jamalpur i.e. (N23JM). This helped create a nesting map within the study area (Figure 2).

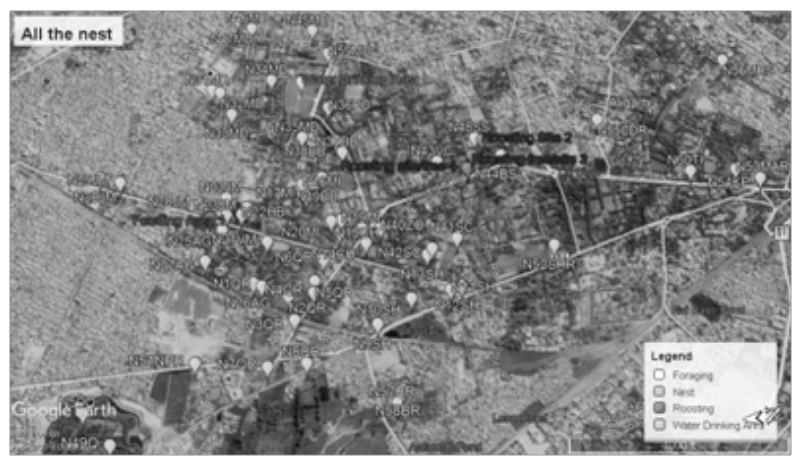

Figure 2 Distribution of the nest sites within the study area.

Various parameters like type of nesting substrate, species of the trees used as nesting substrate, the height of the substrate, branching of the nesting tree, GBH of the tree, Canopy cover above and around the nest, distance from the foraging sites and available green cover within 30meter circular plot; for each nest site was taken. The Girth at breast height $(\mathrm{GBH})$ was measured by fully encircling the tree trunk at 1.37 meter height. Tree/canopy cover was measured using the gridded mirror of $25 \times 25 \mathrm{~cm}$, moving five steps in four cardinal directions, just beneath the nest. The mirror was kept horizontally at $1.25 \mathrm{~m}$ above the ground level and grids covered by foliage were counted and expressed as percent canopy cover. Tree height and nest height was estimated by using the trigonometry method. The landscape variables like the proportional green cover, distance from the foraging site and built up area were obtained using the latest Google Earth imagery of the study area (imagery date: 18/1/2018) within the 30meter plots.

Also to assess the difference between parameters of the available space for nest site selection vs. utilized space for nest site selection, circular plot method was used. One animal-centered plot (Nest plot) i.e. keeping the nest location in the center; a 10 meter radius was plotted while two other random plots of the same radius were taken at two random points, $30 \mathrm{~m}$ away from the animal-centered plot. Tree species, their number, individual height, individual GBH of each tree present in all the plots:- Nest as well as random, were measured.

To calculate an average number of nest per study site, a circular plot of radius 200meters (to keep the area constant) within the different study sites were plotted with the help of circle ruler from the ruler tool in Google Earth program and nest encompassing within each plot were counted. Mostly on an average one plot per study site could be plotted due to the small and irregular area.

To calculate the green cover around each nest site location, a new method was tried by plotting a 30 meter circular plot by the circle ruler from the ruler tool in Google Earth program around the nest area on map. Then it was divided into four equal quarters, again by using a path ruler from the ruler tool. This helped to assess the green cover in each quarter (25\%) separately and then summing it up for the whole plot $(100 \%)$ for each site.

All the data were analyzed using IBM SPSS Software 22.0 version. The correlation between nest height (dependent) and other parameters (independent) was analyzed by using The Pearson product-moment correlation coefficient and to compare the means and investigate its significance for Available vs. utilized data, Student t-test was used.

\section{Results}

In total 75 Pariah kite nest were found within 10 study sites covering an area of $4.21 \mathrm{~km}^{2}$. Several constraints like manpower, feasibility, time, inaccessibility and a few other hindrances associated with the urban environment prohibited from the assessment of all the nests identified. Therefore, for this study, data could be collected from 70 nests $(\mathrm{n}=70)$.

\section{Nesting substrate}

A total number of nests found were seventy $(n=70)$, out of which $60(86 \%)$ were built on trees, while $10(14 \%)$ were built on towers.

\section{Average number of nest per study site}

Most numbers of the nest were at Jamalpur having nine nests per 200meter circular plot and at least at Naqvi Park having 0 nests per 200 meter circular plot.

\section{Nesting parameters}

Overall (trees+towers) mean substrate height for Pariah kite's nest in Aligarh equals to $24.1 \pm 2.8 \mathrm{~m}$, mean nest height is $19.2 \pm 2.2 \mathrm{~m}$, mean GBH is $2.4 \pm 0.2 \mathrm{~m}$, mean canopy cover is $24 \pm 0.03 \%$, mean foraging distance is $599.1 \pm 71.6 \mathrm{~m}$ and mean green cover around $(30 \mathrm{~m})$ is $35 \pm 0.04 \mathrm{~m}$. Also, most of the nest was found in the third quarter of the tree or tower height.

\section{Towers as substrate}

Total $10(14 \%)$ nest were constructed on towers. As seen in the figures, mean height of the nesting towers was $30 \pm 9.5$, mean Height

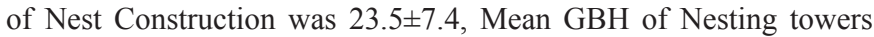
was $5 \pm 1.6$, Mean Canopy on Nesting towers was $0 \pm 0$, Mean foraging Distance from Nesting trees was $685.6 \pm 216.8$ and Mean Green Cover around $(30 \mathrm{~m})$ nesting towers $16.5 \% \pm 0.1$. Also, the Mean difference between tower height and nest height was $6.5 \pm 2.0$. 


\section{Trees as nesting substrate}

Total 6060 nest were constructed on different species of trees $(\mathrm{n}=70)$. The mean height of the nesting trees was $23.1 \pm 0.5$, mean Height of Nest Construction was 20.2 \pm 0.5 , Mean GBH of Nesting trees was $2.02 \pm 0.1$, Mean Canopy of Nesting trees was $28 \% \pm 0.02$, Mean foraging Distance from Nesting trees was $584.8 \pm 50.3$ and Mean Green Cover around $(30 \mathrm{~m})$ nesting tree was $38 \% \pm 0.02$. Also, the Mean difference between tree height and nest height was $4.23 \pm 0.5$.

\section{Tree species used as nesting substrate}

For 60 nest built on trees, a total of 18 tree species was used as substratum, out of 86 recorded tree species in and around AMU campus. Majority of the nest were found on Eucalyptus (Eucalyptus tereticornis), 22 (36.7\%), followed by Jamun (Syzygium cumini), 7 (11.67\%), Neem (Azadirachta indica), 6 (10.00\%), Sheesham (Dalbergia sissoo) 5(8.33\%), Whistling Pine(Casuarina equisetifolia), 4 (6.67\%), Kanak-Champa (Pterospermum acerifolium), 2 (3.33), Kassod tree (Senna siamea), 2 (3.33\%) and Teak (Tectona grandis). Other tree species had one tree each used for nesting.

Results from the independent sample t-test showed highly significant differences in the means of Tree height, nest height and canopy cover in Animal centered from random plots (utilized vs. random). The results of Pearson correlation between parameters of each nest sites were significantly correlated. There was a highly significant positive correlation $(\mathrm{P}<0.01)$ between nest height and tree height $(0.830, \mathrm{P}<0.01)$, nest height and GBH $(0.478, \mathrm{P}<0.01)$ but highly significant negative correlation between nest height and Canopy Cover $(-0.461, \mathrm{P}<0.01)$. Nest height and Distance from foraging site $(0.270, \mathrm{P}<0.05)$ was significantly positively correlated while Nest Height and Green cover were significantly negatively correlated $(-0.243, \mathrm{P}<0.05)$ (Figure 3-6) \& (Table 1-3).

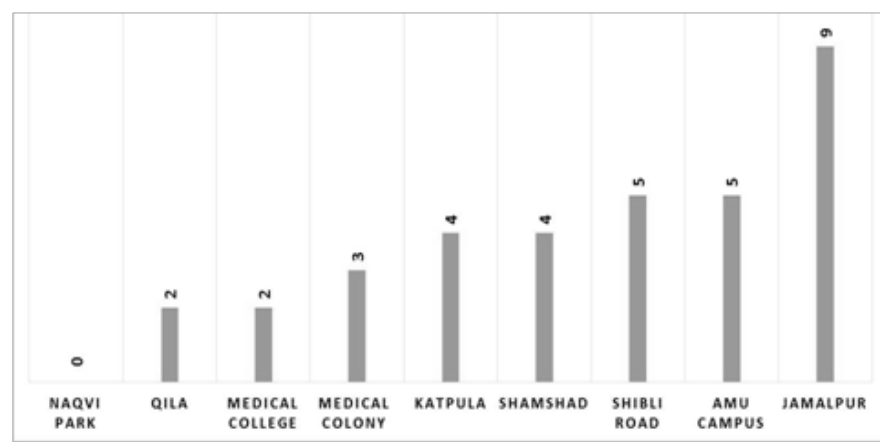

Figure 3 Average number of the nest at each study site.

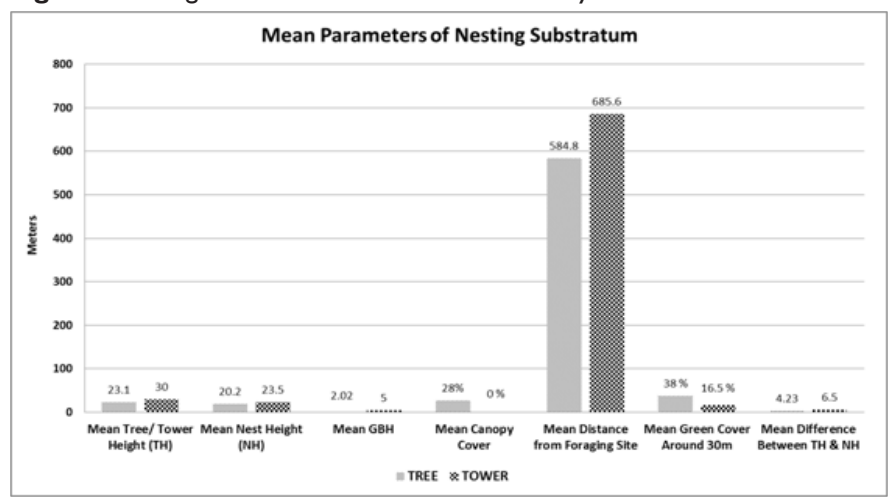

Figure 4 Mean parameters for nesting substrate comparison.
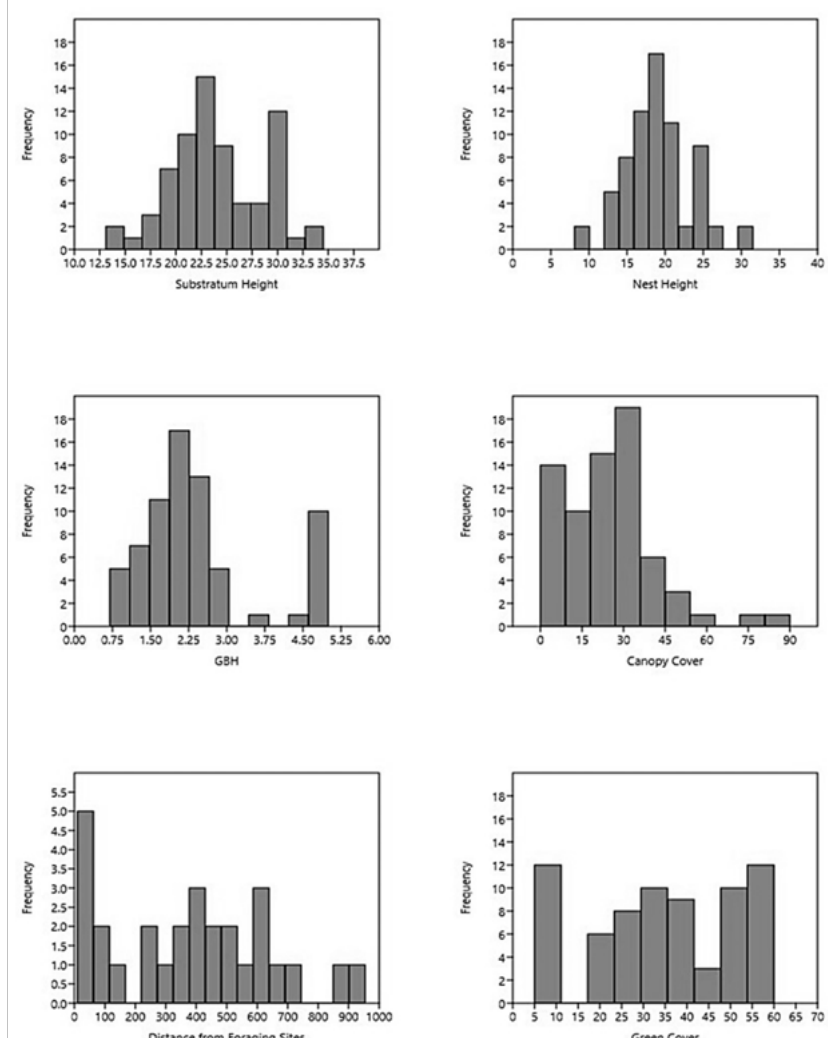

Figure $\mathbf{5}$ Mean nesting parameters of pariah kite nest in Aligarh city.

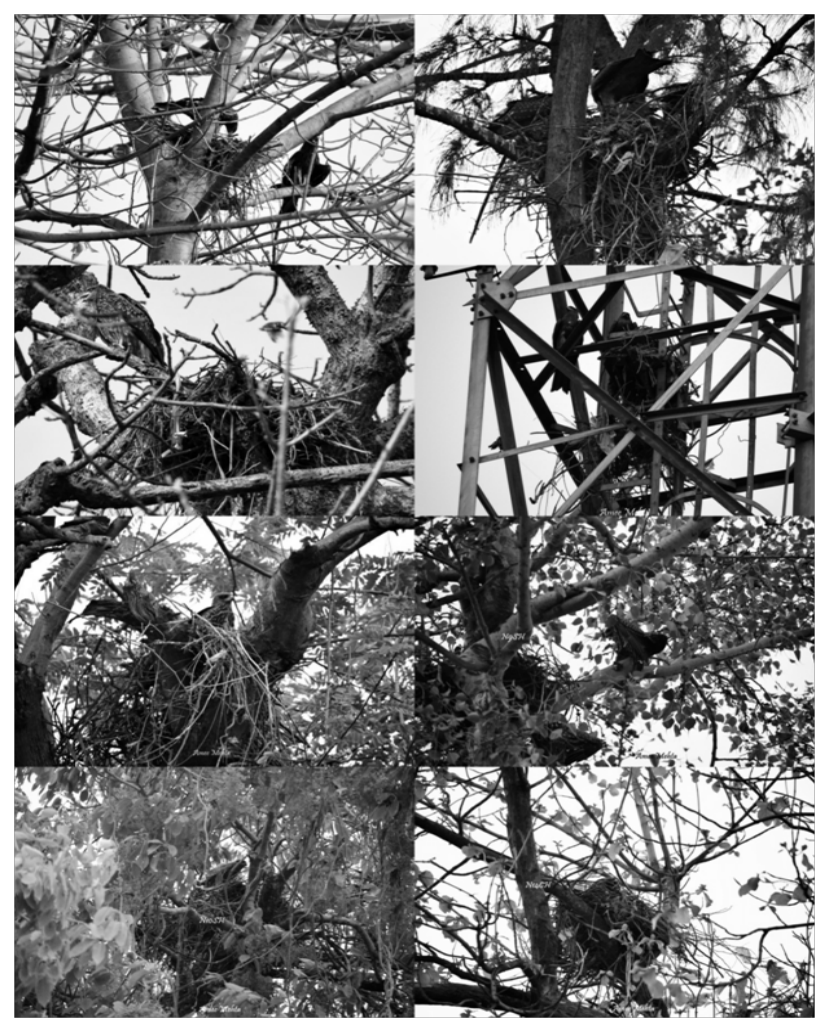

Figure 6 Nesting of pariah kites on the tower and various tree species. 
Table I Pearson correlation coefficient between nest height and other parameters of nest tree nesting

\begin{tabular}{|c|c|c|c|c|c|c|}
\hline Correlations & Tree height & $\begin{array}{l}\text { Nest } \\
\text { height }\end{array}$ & GBH & $\begin{array}{l}\text { Canopy } \\
\text { cover }\end{array}$ & $\begin{array}{l}\text { Distance from foraging } \\
\text { site }\end{array}$ & $\begin{array}{l}\text { Green } \\
\text { cover }\end{array}$ \\
\hline Tree height & I & $0.830 * *$ & $0.576 * *$ & $-0.479 * *$ & $0.345^{* *}$ & -0.143 \\
\hline Nest Height & $0.830 * *$ & I & $0.478 * *$ & $-0.46 \mathrm{I} * *$ & $0.270^{*}$ & $-0.243^{*}$ \\
\hline $\mathrm{GBH}$ & $0.576 * *$ & $0.478 * *$ & I & $-0.388 * *$ & 0.195 & $-0.35 \mathrm{I} * *$ \\
\hline Canopy Cover & $-0.479 * *$ & $-0.46 I^{* *}$ & $-0.388 * *$ & I & -0.029 & $0.237^{*}$ \\
\hline Distance from foraging site & $0.345^{* *}$ & $0.270^{*}$ & 0.195 & -0.029 & I & -0.024 \\
\hline Green Cover & -0.143 & $-0.243 *$ & $-0.35 I * *$ & $0.237^{*}$ & -0.024 & 1 \\
\hline
\end{tabular}

$* * \mathrm{P}<0.01, * \mathrm{P}<0.05$

Table 2 Independent sample t-test for significant differences in mean of the animal and random plots

\begin{tabular}{lllll}
\hline Parameters & $\mathbf{t}$ & $\mathbf{d f}$ & Sig.(two-tailed) & Std. error difference \\
\hline No. of trees & -2.34 & 208 & 0.02 & 0.27167 \\
GBH & -4.774 & 208 & 0 & 0.42779 \\
Height of trees & -8.42 & 208 & 0 & 1.27266 \\
Canopy Cover & -8.752 & 208 & 0 & 2.45482 \\
\hline
\end{tabular}

Table 3 Comparative table for characteristics of trees (specie-vise) used for nesting

\begin{tabular}{|c|c|c|c|c|c|c|}
\hline Tree species \& \% use & No. of nest & $\begin{array}{l}\text { Mean tree } \\
\text { height }(\mathrm{m})\end{array}$ & $\begin{array}{l}\text { Mean nest } \\
\text { height }(\mathrm{m})\end{array}$ & $\begin{array}{l}\text { Difference between } \\
\text { tree height and nest } \\
\text { height }\end{array}$ & $\begin{array}{l}\text { Mean } \\
\text { GBH } \\
(\mathrm{m})\end{array}$ & $\begin{array}{l}\text { Mean canopy } \\
\text { cover }(\%)\end{array}$ \\
\hline $\begin{array}{l}\text { Eucalyptus Eucalyptus } \\
\text { tereticornis }\end{array}$ & $36.67 \%$ & $26.6 \pm 0.8$ & $21.2 \pm 1.0$ & 5.4 & $2.2 \pm 0.1$ & $20 \pm 0.0$ \\
\hline Jamun Syzygiumcumini & $11.67 \%$ & $22.3 \pm 1.0$ & $17.3 \pm 1.1$ & 5 & $2.2 \pm 0.2$ & $49 \pm 0.1$ \\
\hline Neem Azadarictaindica & $10.00 \%$ & $19.8 \pm 0.7$ & $17.1 \pm 1.0$ & 2.7 & $2.3 \pm 0.2$ & $32 \pm 0.0$ \\
\hline Sheesham Dalbergiasisso & $8.33 \%$ & $22.3 \pm 0.7$ & $17.46 \pm 1.1$ & 4.9 & $2.08 \pm 0.2$ & $37 \pm 0.1$ \\
\hline $\begin{array}{l}\text { Whistling Pine } \\
\text { Casuarinaequisetifolia }\end{array}$ & $6.67 \%$ & $20.9 \pm 1.0$ & $17.37 \pm 0.8$ & 3.5 & $1.4 \pm 0.1$ & $28 \pm 0.1$ \\
\hline $\begin{array}{l}\text { KanakChampa } \\
\text { Pterospermumacerifolium }\end{array}$ & $3.33 \%$ & $21.8 \pm 2.8$ & $18.15 \pm 3.0$ & 3.6 & $\mathrm{I} \pm 0.0$ & $13 \pm 0.1$ \\
\hline Kassod tree Sennasiamea & $3.33 \%$ & $15.3 \pm 1.2$ & $11.65 \pm 1.9$ & 3.6 & $2.0 \pm 0.2$ & $25 \pm 0.1$ \\
\hline Teak Tectonagrandis & $3.33 \%$ & $22.3 \pm 0.1$ & $17.43 \pm 1.3$ & 4.9 & $1.5 \pm 0.7$ & $15 \pm 0.1$ \\
\hline Silver Oak Grevillearobusta & $1.67 \%$ & 24.4 & 18.2 & 6.2 & 1.2 & 25 \\
\hline $\begin{array}{l}\text { AakashNeem } \\
\text { Millingtoniahortensis }\end{array}$ & $1.67 \%$ & 23.5 & 17.4 & 6.2 & 2.8 & 40 \\
\hline Peepal Ficusreligiosa & $1.67 \%$ & 23 & 18.5 & 4.6 & 2.4 & 30 \\
\hline Cotton Tree Bombaxceiba & $1.67 \%$ & 22.2 & 17.7 & 4.5 & 2.1 & 0 \\
\hline
\end{tabular}




\begin{tabular}{|c|c|c|c|c|c|c|}
\hline Tree species \& \% use & No. of nest & $\begin{array}{l}\text { Mean tree } \\
\text { height }(m)\end{array}$ & $\begin{array}{l}\text { Mean nest } \\
\text { height }(m)\end{array}$ & $\begin{array}{l}\text { Difference between } \\
\text { tree height and nest } \\
\text { height }\end{array}$ & $\begin{array}{l}\text { Mean } \\
\text { GBH } \\
(\mathrm{m})\end{array}$ & $\begin{array}{l}\text { Mean canopy } \\
\text { cover (\%) }\end{array}$ \\
\hline $\begin{array}{l}\text { Banyan Tree } \\
\text { Ficusbenghalensis }\end{array}$ & $1.67 \%$ & 21.7 & 17.8 & 3.9 & 4.6 & 50 \\
\hline Pilkhan Ficusvirens & $1.67 \%$ & 21.5 & 19.4 & 2.1 & 2.3 & 10 \\
\hline Gulmohar Delonixregia & $1.67 \%$ & 21.3 & 18.7 & 2.6 & 0.8 & 30 \\
\hline Goolar Ficusglumerata & $1.67 \%$ & 20.8 & 15.1 & 5.7 & 1.8 & 30 \\
\hline Ashoka Polyalthialongifolia & $1.67 \%$ & 20.3 & 18.4 & 1.9 & 1.3 & 40 \\
\hline Babool Acacia nilotica & $1.67 \%$ & 13.1 & 8.1 & 5 & 0.7 & 50 \\
\hline
\end{tabular}

\section{Discussion}

A total of $86 \%$ nest were made on natural substrate i.e. trees and $14 \%$ on artificial i.e. towers, pylons. This signifies their selective nature and preference for the natural substrates. ${ }^{6,11}$

It was clearly seen that the preference was given to the tree with huge height and big GBH. This proves that they prefer big trees with strength. This could be seen as most of the nesting $(22.7 \%)$ were on Eucalyptus tree with an average height of 26 meters and GBH of 2.2 meters. ${ }^{11,13}$

Our results indicate Pariah Kite appears to have a preference for nesting on Eucalyptus trees. Apart from its relatively larger height, GBH, less canopy cover its high use was justified because of its high relative availability at all the sites. ${ }^{9,11}$ Also due to its V-shaped terminating branches, this may be useful for securely fastening the nests, giving a huge and strong base.

High nest number at Jamalpur ( 9 nests/200m circular plot) was justified as it is a busy market with meat shops, dump yard and with an average of $50 \%$ green cover comprising of Eucalyptus trees and high towers thus providing food, nesting and roosting sites. Whereas Naqvi park has high tree density, high canopy cover and high green cover which is not favored for nesting and with scarce resources nearby. Almost the same observations were made on this species in the Delhi area by and Science, Kumar, The, \& Of. ${ }^{11}$ This clearly suggests the selective behavior of Pariah Kites for nesting near foraging areas i.e mostly dumb yards which were near urban areas with less green cover. Nesting densities were influenced by the distance from the foraging sites. As the distance increases, the nest densities decreased. ${ }^{12,13}$

Areas with high densities like Jamalpur, AMU Campus, Shibli road, Shamshad, Katpulla were more or less similar in terms of ratios of green cover and urbanization (30:70) with the high relative availability of Eucalyptus, favoring nesting. A highly significant negative correlation with these two parameters was found, justifying the reason that more urbanized area with dump yard i.e foraging site will have less green cover. Jamalpur having the highest nest number comprise less green cover than Naqvi park and Qila. ${ }^{9,11}$ Also, the less canopy on the nest might be due to easy entry and exit to the nest because of the huge wingspan which needs space to open to take off and land. Also for the better vigilance. This could also be justified by $14 \%$ of nesting on towers which have almost no green cover around and no canopy cover been used as roosting and nesting site.

The nest density and roosting sites to be more near the dump sites. It was seen that the nesting density and roosting sites increased as the distance from the dump sites decreased. Breeding Milvus migrans forage preferentially nearby dump yards ${ }^{13,14}$ which minimize their foraging trips and also maximize the optimal foraging habitat around the nest. ${ }^{15}$

\section{Acknowledgements}

The authors are grateful to the Department of Wildlife Sciences, Aligarh Muslim University for providing the atmosphere and facilities to conduct this study. Thanks to Prof. Affifullah Khan, Chairman, Department of Wildlife Sciences and Dr. Satish Kumar for valuable inputs. The first author is also thankful to Prof. H.S.A Yahya, for always nurturing hir interest in birds. The study was done for the M.Sc. dissertation work of the first author at the Department of Wildlife Sciences, Aligarh Muslim University.

\section{Conflict of interest}

The author declares no conflict of interest.

\section{References}

1. Tuomenpuro J. Effect of nest site on nest survival in the Dunnock Prunellamodularis. OrnisFennica. 1991;68(2):49-56.

2. Godshe SV. Ecology of Black Kite (Milvus migrans govinda) with quantification of heavy metals in various tissues. Gujarat: The Maharaja Sayajirao University of Baroda; 2014.

3. Rendell WB, Robertson RJ. Nest-site characteristics, reproductive success and cavity availability for Tree Swallows breeding in natural cavities. Condor. 1989;91:875-885.

4. Li P, Martin TE. Nest-Site Selection and Nesting Success of Cavity-Nesting Birds in High Elevation Forest Drainages. The Auk. 1991;108(2):405-418.

5. Cringan AT, Horak GC. Proceedings of the Western Raptor Management Symposium and Workshop, National Wildlife Federation, Washington, DC. Effects of urbanization on raptors in the western United States; 1989. p. 219-228.

6. Kumar N, Mohan D, Jhala YV, et al. Density, laying date, breeding success and diet of Black Kites Milvus migrans govinda in the city of Delhi (India). Bird Study. 2014;61(1):1-8

7. Ali S, Ripley SD. Handbook of the Birds of India and Pakistan: together with those of Bangladesh, Nepal, Sikkim and Sri Lanka Compacted. In: Divers, Hawks, editors. Delhi: Oxford University Press; 1983:226-229.

8. Prakash V, Bishwakarma MC, Chaudhary A, et al. The Population Decline of Gyps Vultures in India and Nepal Has Slowed since Veterinary Use of Diclofenac was Banned. PLoS ONE. 2012;7(11):e49118. 
9. Kumar N, Gupta U, Jhala YV, et al. Habitat selection by an avian top predator in the tropical megacity of Delhi: human activities and socio-religious practices as prey-facilitating tools. Urban Ecosystems. 2018;21(2):1-11.

10. Malhotra AK. Tiger of sky-Pariah Kite. Delhi: Shilalekh Publishers; 2007.

11. Science INW, Kumar N, The U, et al. A Study of Resource Selection by Black Kites (Milvusmigrans) in the Urban Landscape of National Capital Region, India: Wildlife institute of India; 2013.

12. Mazumdar S, Ghose D, Saha GK. Foraging strategies of black kites (Milvusmigransgovinda) in urban garbage dumps. Journal of Ethology. 2016;34(3):243-247.
13. Sergio F, Boto A. Nest dispersion, diet, and breeding success of Black Kites (Milvusmigrans) in the Italian pre-Alps. Journal of Raptor Research.1999;33(3):207-217.

14. Roberts KS. The development of behavior in nestling Ospreys. 1982.

15. Sergio F, Pedrini P, Marchesi L. Adaptive selection of foraging and nesting habitat by black kites (Milvus migrans) and its implications for conservation: A multi-scale approach. Biological Conservation. 2003;112(3):351-362. 